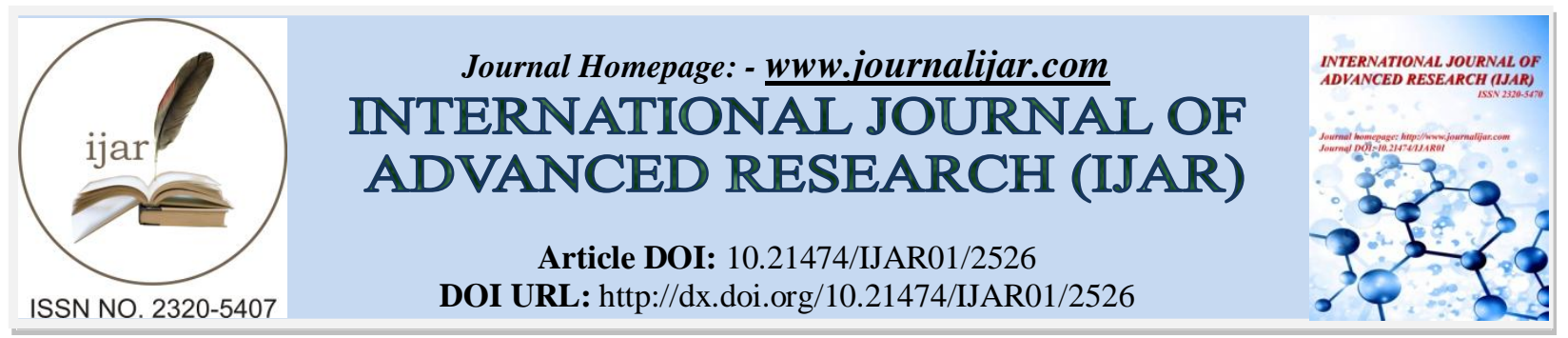

RESEARCH ARTICLE

\title{
STUDIES ON ANTIBACTERIAL, ANTIOXIDANT AND ANTICANCEROUS ACTIVITY USING ESSENTIAL OIL FROM CYMBOPOGON FLEXUOSUS (STAPF).
}

Vinutha Marigowda ${ }^{1}$, Hemalatha $\mathbf{J}^{2}$, Ashwini $\mathbf{M}^{2}$, Shivakameshwari $\mathbf{M ~ N}^{3}$ and ${ }^{*}$ Thara Saraswathi $K \mathrm{~J}^{4}$.

1. Department of Biotechnology, Bangalore University, Jnanabharathi Campus, Bengaluru, Karnataka, India.

2. Research scholar, Department of Microbiology and Biotechnology, Jnana Bharathi Campus, Bangalore University, Bengaluru - 560056.

3. Assistant Professor, Dept. of Botany, Bangalore University, Bengaluru-560056.

4. Professor, Department of Microbiology and Biotechnology, Jnana Bharathi Campus Bangalore University, Bengaluru-560056.

\section{Manuscript Info}

Manuscript History

Received: 25 October 2016

Final Accepted: 23 November 2016

Published: December 2016

Key words:

Cymbopogon flexuosus, essential oil, Antibacterial, Antioxidant, Anticancer

\section{Abstract}

Cymbopogon flexuosus (Stapf) is an aromatic and medicinal grass commonly known as East Indian lemongrass belonging to the family Poaceae. The grasses possess lemon scented essential oil used widely in flavor, perfumery, food and pharmaceutical industries. The use of natural essential oil in medicine is potent and safe due to their harmless nature. The indiscriminate use of commercial antimicrobial drugs for the treatment of infectious disease has led to increased resistance of the organisms and there is a need for search for new antimicrobial substances from various sources including medicinal plants. The essential oils have been used widely as antibacterial agents against pathogenic organisms. The essential oils are known to possess antioxidant activity which is gaining great interest as they act as human health protecting factors and preserve foods from the toxic effects of oxidants. As the essential oil contain great number of chemical constituents, it seems to have no specific cellular targets. A major advantage of essential oils is that they are usually devoid of long-term genotoxic risks. The oils show clear antimutagenic capacity which could be linked to its anticarcinogenic activity. The aim of the present study was to assess the antimicrobial, antioxidant and anticancer activities of essential oil extracted from the aerial and subaerial part of UV treated plants of $C$. flexuosus.

Copy Right, IJAR, 2016,. All rights reserved.

\section{Introduction:-}

Cymbopogon is one of the major aromatic and medicinal plant genera belonging to the tribe Andropogoneae of the family Poaceae. The Cymbopogon species can be distinguished from other genera by their aromatic smell in the same tribe. About 180 species, sub-species, varieties and sub- verities are distributed in tropical and sub-tropical regions of Asia, Africa, America, Australia and Europe. In India, this grass is grown wild in all regions extending from sea level to higher altitudes of $4200 \mathrm{~m}$. The commercially utilized Cymbopogon species include C. flexuosus (East Indian lemongrass), C. winterianus (citronella), C. martinii (Palmarosa) and C. pendulus (North Indian lemongrass) etc.

Corresponding Author:- Thara Saraswathi K J.

Address: Professor, Department of Microbiology and Biotechnology, Jnana Bharathi Campus Bangalore 
Cymbopogon flexuosus (Stapf) is one of the major aromatic grasses dealt under commercial Cymbopogons. The plant is commonly known as East Indian lemongrass / lemongrass / Cochin grass / Malabar grass. This lemongrass is native to peninsular India, the wild form being restricted to Kerala (Joy, 2006), in addition to their distribution in Sri Lanka, Burma and Thailand. Commercially the species is cultivated in Kerala, Assam, Maharashtra, Uttar Pradesh and Gujarat. The lemongrass is a perennial herb and the yield is harvested frequently at regular intervals in the tropics. The prefix 'lemon' in the lemongrass owes to its typical lemon like odor released upon maceration of leaves.

Due to high commercial value and increased demand for C. flexuosus, there is need for continuous supply of quality essential oil and increasing their number in cultivation for higher essential oil yield is crucial to meet the growing demand (Uniyal et al. 2000). In view of this, selecting the wild genotypes having quality traits increase the opportunities of this grass for their economic development (Sangwan, 2003). In comparison to the wild populations, the continuous developmental process of cultivars has lead to gradual loss of genetic diversity, besides lowering the active ingredients in fast-growing cultivar stocks (Schippmann et al., 2006). The essential oils of Cymbopogon species posses active ingredients and thus exhibit characteristic aroma and potent bioactivity (Bakkali et al., 2008).

C. flexuosus yield one of the top ten major essential oils in the World (Lawerence, 1985). The oil has high economic value and India produces more than 350 tonnes of oil out of which $80 \%$ is exported. The International production of oil is around 1000 tonnes out of which 300 tonnes is exported by India (Aromatic and Medicinal Plants Research Station, KAU, Odakkali-2015). The oil is used to produce high grade perfumes and in the synthesis of soaps, cosmetics, flavours besides aroma therapy (Adinarayan et al., 2012). The bioactivity studies performed showed anticancer (Sharma et al., 2009), analgesic, anti-inflammatory (Chandrashekar et al., 2010), antibacterial (FazrullahInnsan et al., 2011) and antiviral properties (Chao et al., 2000). The oil is used as preservative due to the hydrophobic nature, for long term storage of manuscripts (Sahoo et al., 2004). During the present investigation, the genotypes of $C$. flexuosus sourced out from the wild were sourced out to select the elite gene pool which was further explored for antimicrobial, antioxidant and anticancer activities.

Wide inter and intraspecific differences have been reported in response to UV-B for plant growth and morphogenetic response (Milchunas et al., 2004) and for physiological processes (Tsormpatsidis et al., 2010). Some species exhibit varied degree of tolerance attributed to effective absorption of UV-B by the secondary metabolites produced by plants (Zu et al., 2011). During the present investigation, the essential oil from UV-B irradiated $C$. flexuosus were studied for antioxidant, antimicrobial and anticancer activities.

\section{Materials and methods:-}

Collection and Maintenance of Germplasm:-

C. flexuosus were collected from Himavad Gopala hills (H.G hills), Karnataka and maintained in the Departmental garden of Microbiology and Biotechnology, Bangalore University, Bangalore. The plants were subjected to UV treatment for 1.5 hours and used for the studies.

\section{Essential oil studies:- \\ Extraction:-}

The aerial and Sub aerial part of C. flexuosus of Control and UV treated plants were used for extraction of essential oil. For extraction of essential oil the herbage was cut into small pieces (approximately $25 \mathrm{~mm}$ length) and fresh weight was noted. The herbage was air dried at room temperature and dry weight was recorded. Extraction of essential oil was carried out by hydrodistillation method for three hours using Clevenger's apparatus. The volume of essential oil recovered was recorded. The oil thus obtained was stored using anhydrous sodium sulphate in dark bottle under refrigerated conditions till further use.

\section{Analysis:-}

\section{Gas Chromatographic-Mass Spectral analysis:-}

GC-MS analysis of the extract was performed on an Agilent Technologies gas chromatograph Model 5973N equipped with mass selective detector. A CPSil8CB column (30m X $0.25 \mathrm{~mm}$ X $0.25 \mathrm{Mm}$ film thickness) coated with dimethylpolysiloxane with 5\% diphenyl as the stationary phase. Helium was used as the carrier gas at a flow rate of $1 \mathrm{~mL}$ per min. (constant flow). Temperature programming was done from $50^{\circ} \mathrm{C}(2 \mathrm{~min})$ to $280^{\circ} \mathrm{C}$ at $10^{\circ} \mathrm{C}$ per min. Injector and detector temperature were maintained at $250^{\circ} \mathrm{C}$ and $280^{\circ} \mathrm{C}$ respectively. Samples of $1 \mu \mathrm{L}$ dissolved in hexane were injected using a split ratio of 10:1. Mass spectra were recorded in the EI mode at 70eV in the $\mathrm{m} / \mathrm{z}$ range of $30-450$. 


\section{Identification of compounds:-}

The essential oil components were identified by comparison of the mass spectra of the peaks with those of compounds from literature (Adams, 2007) and those stored in NIST library. Peak area percentages were computed from GC peak areas without using correction factor.

\section{Antibacterial activity:-}

\section{Determination of Minimum inhibitory concentration (MIC):-}

Preparation of stock solution:-

$100 \mathrm{mg}$ of essential oil was weighed and dissolved in $1 \mathrm{ml}$ of DMSO. Ciproflaxacin was dissolved in ethanol to give a concentration of $10 \mathrm{mg} / \mathrm{ml}$. The essential oils were serially diluted in sterile Muller Hinton Broth (MHB) to give a twofold diluted concentrations ranging from $512-1 \mu \mathrm{g} / \mathrm{ml}$. Similarly Ciproflaxacin was diluted in MHB to give the final concentration ranging from $128-1 \mu \mathrm{g} / \mathrm{ml}$.

\section{Preparation of inoculum:-}

Gram negative bacteria such as Escherichia coli (O157:H7 ATCC 43895), Shigella dysenteriae (ATCC 13313), Salmonella typhii (ATCC 14028) and Pseudomonas aerugenosa (ATCC 27853) were selected to determine the antibacterial activity of $C$. flexuosus essential oil.

The test cultures were grown overnight (16-18 hrs) on nutrient agar plates. A loop full of culture was suspended in $0.85 \%$ saline and the optical density at $620 \mathrm{~nm}$ of culture suspension was adjusted to 0.15 ( $0.5 \mathrm{McFarland})$. The Inoculums are diluted with 2 volumes of MHB to give the final cell density of $10^{5}$ per well.

\section{Evaluation of MIC:-}

Two fold dilutions of Essential oils (100 $\mu \mathrm{L})$, Ciproflaxacin Std (100 $\mu \mathrm{L})$ and MHB (100 $\mu \mathrm{L})$ used as Control, were dispensed aseptically into 96 well plate. The test organisms $(50 \mu \mathrm{L})$ were inoculated into each well and incubated at $37^{\circ} \mathrm{C}$ for $18-24 \mathrm{hrs}$. The optical densities at $620 \mathrm{~nm}$ of incubated plates were measured in Tecan Plate Reader (Switzerland). The MIC endpoint was defined as concentration of test compounds showing $50 \%$ inhibition of growth and compared with the Control.

\section{Antioxidant activity:-}

The antioxidant activities of essential oil from control and UV treated (Aerial and Sub aerial parts) C. flexuosus along with the Std (Citral and Rutin) were evaluated by using three different antioxidant assays such as Nitric oxide assay, ABTS assay and Total Antioxidant Capacity.

\section{Scavenging of Nitric Oxide radical (NO):-}

Sodium nitroprusside in aqueous solution at physiological $\mathrm{pH}$ spontaneously generate nitric oxide, which interact with oxygen to produce nitrite ions. This is estimated by using Griess Ilosvay reaction (Griess, 1879). Griess Ilosvay reagent was modified by using naphthyl ethylene diamine dihydrochloride $(0.1 \% \mathrm{w} / \mathrm{v})$ instead of 1 -napthylamine $(5 \%)$. The nitrite ions react with Griess reagent to form a purple azo dye. In the presence of essential oils (likely to be scavengers), the amount of nitrite decreases. The degree of decrease in the formation of purple azo dye reflects the extent of scavenging. The absorbance of the chromophore formed was measured at $540 \mathrm{~nm}$ (Garrat, 1964; Nenadis et al., 2004).

\section{Scavenging of ABTS radical cation Assay:-}

2, 2'-azino-bis (3-ethylbezothiazoline-6-sulfonic acid) diammonium salt) (ABTS) (54.8 mg) was dissolved in $50 \mathrm{ml}$ of distilled water to $2 \mathrm{mM}$ concentration and added with potassium persulphate $(17 \mathrm{mM}, 0.3 \mathrm{ml})$. The reaction mixture was left to stand at room temperature overnight in dark before use. To $0.2 \mathrm{ml}$ of various concentrations of the essential oil and the Std, $1.0 \mathrm{ml}$ of distilled DMSO and $0.16 \mathrm{ml}$ of ABTS solution was added making the final volume to $1.36 \mathrm{ml}$. The absorbance was measured spectrophotometrically after $20 \mathrm{~min}$ at $734 \mathrm{~nm}$ (Arnao et al., 2001).

\section{Evaluation of Total Antioxidant Capacity:-}

The total antioxidant capacity was determined by phosphor-molybdenum method. An aliquot of $0.1 \mathrm{ml}$ of essential oil solution containing reducing species in DMSO was mixed in Eppendoff tube with $1 \mathrm{ml}$ of reagent solution $(0.6 \mathrm{M}$ Sulphuric acid, $28 \mathrm{mM}$ sodium phosphate, and $4 \mathrm{mM}$ ammonium molybdate). The tubes were incubated in water bath at $95^{\circ} \mathrm{C}$ for $90 \mathrm{~min}$. The samples were cooled to room temperature and absorbance of each solution was measured at 
$695 \mathrm{~nm}$. The total antioxidant capacity was expressed as mM equivalent of ascorbic acid (Mojca et al., 2005)

Anticancer activity:-

The Cytotoxic activity of essential oil of both Control and UV treated (Aerial and Sub aerial parts) plants were screened by MTT assay. The anticancer activity was analysed through Haemolysis assay, Clonogenic assay, DNA ladder assay and Cell cycle analysis.

MTTassay (3-[4,5-dimethylthiazol-2-yl]-2,5-diphenyl tetrazolium bromide):-

The essential oil of both Control and UV treated plants was screened for cytotoxic activity against Breast Cancer cell line (MCF-7). The MCF-7cell lines were trypsinized to 70-80\% confluent and checked for the viability of cells and centrifuged. The MCF-7 (60,000 cells / well) cells were seeded into 96 well plates and incubated for $24 \mathrm{~h}$ at $37^{\circ} \mathrm{C}$ in $5 \% \mathrm{CO}_{2}$ incubator. The essential oil was prepared at different concentrations ranging from $0,10,20,40,80$, $120,160,320 \mu \mathrm{g} / \mathrm{ml}$ (2 fold variations) in DMEM without foetal bovine serum (FBS) and antibiotics (penicillin and streptomycin) and were incubated for $24 \mathrm{hr}$. After incubation, the media was removed from wells and MTT reagent was added at concentration of $50 \mu \mathrm{g} /$ well $[5 \mathrm{mg} / 10 \mathrm{ml}$ of MTT in $1 \mathrm{X}$ phosphate buffer saline (PBS)]. The solution was filtered through $0.2 \mathrm{~mm}$ filter and stored at $2-8^{\circ} \mathrm{C}$ and incubated for $3-4$ hours. After incubation, the wells were observed for purple colour crystal (Formazan) formation. The media was removed from the wells and $100 \mu 1$ of dimethyl sulfoxide (DMSO) was added to rapidly solubilize the Formazan. Absorbance was measured at $590 \mathrm{~nm}$ and the cytotoxic effect was calculated using the formula, \% of Inhibition $=100-($ Sample/Control) X 100

\section{Haemolysis Assay:- Isolation of Erythrocytes:-}

$5 \mathrm{ml}$ of blood was collected from healthy volunteers in the tubes containing $5.4 \mathrm{mg}$ of EDTA to prevent coagulation and centrifuged at $1000 \mathrm{rpm}$ for $10 \mathrm{~min}$ at $4^{0} \mathrm{C}$. Plasma was removed carefully and the white puffy layer was completely removed by aspiration using the pipette. The erythrocytes were washed thrice with $1 \mathrm{X} \mathrm{PBS}$ at $\mathrm{pH} 7.4$ for $5 \mathrm{~min}$ and stored at $4^{\circ} \mathrm{C}$. The processed erythrocytes were used for haemolysis assay within $6 \mathrm{hrs}$. The Erythrocyte suspension of $50 \mu \mathrm{l}$ of 10 dilution (100 $\mu$ l Erythrocyte suspension: $900 \mu \mathrm{l}$ 1XPBS) was taken and $100 \mu \mathrm{l}$ of essential oil samples (Control and UV treated plants) are added. $100 \mu \mathrm{l}$ of 1X PBS was used as negative control, $100 \mu \mathrm{l}$ of $1 \%$ Triton X-100 and $100 \mu \mathrm{l}$ of $1 \%$ SDS were used as positive controls. The reaction mixture was incubated at $37^{\circ} \mathrm{C}$ in water bath for $60 \mathrm{~min}$. The volume of reaction mixture was adjusted to $1 \mathrm{ml}$ by adding $850 \mu \mathrm{l}$ of $1 \mathrm{X}$ PBS. The suspension was centrifuged at $300 \mathrm{rpm}$ for $3 \mathrm{~min}$ and the resultant haemoglobin in supernatant was measured at 540 $\mathrm{nm}$ by spectrophotometer to determine haemoglobin concentration.

Haemolysis percentage was determined using the formula,

$\%$ Haemolysis $=\frac{(\text { Control }- \text { Sample })}{\text { Control }} \times 100$

\section{Clonogenic Survival Assay:-}

The MCF-7cells were plated at $2 \times 10^{3}$ cells/well (24 well plates) containing Dulbecco's Modified Eagle's Medium (DMEM) supplemented with FBS and incubated at $37^{\circ} \mathrm{C}$ in $5 \% \mathrm{CO}_{2}$ for $24 \mathrm{~h}$. After incubation, the cells were treated with $320 \mathrm{mg} / \mathrm{ml}$ of essential oil for 24 hour, allowed to grow adding fresh media and incubated for 14 days to obtain >50 cells/ colony. Later, the media was removed and washed with ice-cold PBS. The colonies were stained with $1 \mathrm{ml}$ of $1 \%$ crystal violet in $80 \%$ methanol for 30 minutes on a rocking platform. They were rinsed three times with PBS, air-dried and colonies were counted. The photographs were taken at $4 \mathrm{X}$ using Inverted microscope.

\section{DNA Ladder Assay:-}

The MCF-7 cells were treated with essential oils (Control and UV treated plants) and subjected to DNA ladder assay. Adherent and detached MCF-7 cells were harvested and washed with phosphate buffered saline (1X PBS). Approximately $2 \times 10^{5}$ cells were lysed with lysis buffer $(50 \mathrm{mM}$ Tris- $\mathrm{HCl}, 10 \mathrm{mM}$ ethylene diamine tetra acetic acid (EDTA)-Na and $0.5 \%$ sodium-N-lauroylsarcosinate) at $\mathrm{pH} 7.8$. The lysates were incubated in the lysis buffer containing $0.33 \mathrm{mg} / \mathrm{ml} \mathrm{RNase} \mathrm{A}$ at $50^{\circ} \mathrm{C}$ for $30 \mathrm{~min}$ and were further incubated in the lysis buffer containing 0.33 $\mathrm{mg} / \mathrm{ml}$ proteinase $\mathrm{K}$ at $50^{\circ} \mathrm{C}$ for $30 \mathrm{~min}$. Equal amount of DNA was electrophoresed on $2.0 \%$ agarose gel. The gels were stained with $0.5 \mathrm{mg} / \mathrm{ml}$ of ethidium bromide for $15 \mathrm{~min}$ and visualized under UV light. 


\section{Cell Cycle Analysis:-}

The MCF-7 cell lines were cultured in 6-well plate containing $2 \mathrm{ml}$ of DMEM (Gibco USA) to obtain the cell density of $1.8 \times 10^{6}$ cells. After $24 \mathrm{~h}$ of incubation, the spent media was removed and the cells were washed with $1 \mathrm{X}$ PBS. Essential oils from aerial part of Control and UV treated plants was added ( $1 \mathrm{ml} /$ well) at concentration of 320 $\mu \mathrm{g} / \mathrm{ml}$ and incubated for $24 \mathrm{~h}$. After treatment, the media was removed, cells were washed with 1X PBS and both floating and adherent cells were collected by Trypsin-EDTA. Pellet of $10^{5}$ cells / $\mathrm{ml}$ was collected by centrifugation at $1500 \mathrm{rpm}$ for $5 \mathrm{~min}$ at room temperature and supernatant discarded. The cell pellet was suspended gently with two washes in 1XPBS and fixed overnight at $4^{\circ} \mathrm{C}$ in $500 \mu \mathrm{l}$ of fixing solution (15\% FBS and $15 \%$ PBS in $70 \%$ ethanol). The fixed cells were centrifuged at $1500 \mathrm{rpm}$ for $5 \mathrm{~min}$ at room temperature and supernatant discarded. The cell pellet was washed twice with cold 1XPBS and incubated for $1 \mathrm{~h}$ at room temperature in $500 \mu \mathrm{l}$ of propidium iodide (PI) solution containing $0.05 \mathrm{mg} / \mathrm{ml}$ PI, $0.1 \mathrm{~mm}$ EDTA and $0.05 \mathrm{mg} / \mathrm{ml}$ RNase-A in PBS. The cells were incubated for $1 \mathrm{~h}$ at room temperature in $500 \mu \mathrm{l}$ of propidium iodide (PI) solution containing $0.05 \mathrm{mg} / \mathrm{ml} \mathrm{PI}, 0.1 \mathrm{~mm}$ EDTA, and $0.05 \mathrm{mg} / \mathrm{ml} \mathrm{RNase} \mathrm{-A} \mathrm{in} \mathrm{PBS.} \mathrm{The} \mathrm{percentage} \mathrm{of} \mathrm{cells} \mathrm{in} \mathrm{various} \mathrm{stages} \mathrm{of} \mathrm{cell} \mathrm{cycle} \mathrm{was} \mathrm{determined} \mathrm{using}$ FACS Canto II Flow Cytometer (BD Biosciences, San Jose, CA) and analyzed by Flow Jo version 7.5.5 software (Tree Star, Inc., Ashland, OR).

\section{Results:-}

\section{Essential oil analysis:-}

The essential oils from Aerial part of the Control and UV treated plants were assessed for their physical characteristics based on their color, odor, refractive index, specific gravity and optical rotation. The essential oil obtained from aerial part of the Control and UV treated plants was dark yellow in color with citrus aroma. The oils exhibited refractive index of 1.4857 and 1.4876 respectively. The specific gravity of the essential oil from Control plants was found to be 0.8746 and UV treated showed 0.8835 . The optical rotation of essential oil from Control was $[-] 1.25$ and in UV treated was [-] 1.42 respectively.

The essential oils from sub- aerial part of the Control and UV treated plants were pale yellow in color with mild aroma of the lemon. The values of refractive index, specific gravity and optical rotation were found to be higher than the aerial part. The oils of sub-aerial part exhibited refractive index of 1.5021in Control and 1.5010 in UV treated plants. The specific gravity was found to be 0.8912 and 0.8954 in essential oils of the Control and UV treated plants respectively. The optical rotation of essential oil from the Control was [-] 2.04 and in essential oils from UV treated plants was [-] 2.24 respectively.

The essential oils from aerial part of the Control and UV treated C. flexuosus were analysed by Gas chromatography for identification of important compounds (Fig.1\&2). The result indicated the presence of Geranial (35.13\%), Neral (29.85\%), Linalool (0.7\%), Citronellal (0.43\%) and Geranyl acetate $(2.50 \%)$ in the essential oil of Control plants. The oil from UV treated plants showed increase in the percentage of compounds like Geranial (51.10\%), Neral (34.50\%), Linalool (1.02\%), Citronellal (0.47\%) and Geranyl acetate $(3.91 \%)$.

The analysis of essential oil from aeial part of the Control (Fig 1 and Table 1) and UV treated plants are shown (Fig 2 and Table 2). The sub-aerial part of the Control plants showed presence of Citral and its isomers (Neral and Geranial) in higher percentages (Fig 3 and Table 3). There was high reduction in the level of Citral observed in UV treated plants (Fig 4 and Table 4). The UV treated plants showed the presence of new compounds like indole nitrofuryl oxadiazole and 2-tetrahydro furfuryl isothiocyanate upto 83\% (Fig $3 \& 4$ ). The Gas Chromatogram of Standard Citral is shown (Fig 5).

\section{Antibacterial Activity:-}

The antibacterial activity of essential oil from the Control and UV treated plants (aerial and sub-aerial parts) were determined by MIC with different concentrations $(1,4,16,64,128,256$ and $512 \mu \mathrm{g} / \mathrm{ml})$ and were tested against Escherichia coli, Salmonella typhii, Salmonella dysenteriae and Pseudomonas aeruginosa. The antibiotic Ciproflaxacin $(1,2,4,8,16,32,64,128 \mu \mathrm{g} / \mathrm{ml})$ was used as Positive control and DMSO as Negative control.

The essential oil samples showing MIC activity of $512 \mu \mathrm{g} / \mathrm{ml}$ for the microorganisms tested during the study is shown (Table 5, 6, 7 and 8). The oil from sub aerial part UV treated plant showed high inhibitory activity with MIC $64 \mu \mathrm{g} / \mathrm{ml}$ in $E$ coli compared to the Control, Std Citral and other micro organisms (Table 5). The oil from aerial part of UV treated plant showed inhibitory activity of microorganisms at MIC $512 \mu \mathrm{g} / \mathrm{ml}$. The comparison of inhibitory activity of microorganisms is shown (Table 9). 


\section{Antioxidant activity:-}

The antioxidant activity of essential oils from aerial part (Control, UV treated - 1.5h) and sub-aerial parts [Control, UV treated - $1.5 \mathrm{~h}$ (Citral rich), $1.0 \mathrm{~h}$ (Geranial rich) and $0.25 \mathrm{~h}$ (Neral rich)] were determined by Nitric Oxide assay (NO), ABTS assay and Total Antioxidant Capacity (TAC) (Table 10). The essential oil from aerial part of Control plants showed moderate Nitric Oxide scavenging activity with $\mathrm{IC}_{50}$ value of $270 \pm 0.00$ compared to UV treated plants showing $\mathrm{IC}_{50}$ value of $310 \pm 10 \mu \mathrm{g} / \mathrm{ml}$. The essential oil from sub-aerial part of UV treatment $-0.25 \mathrm{~h}$ (Neral rich) showed high Nitric Oxide scavenging activity with $\mathrm{IC}_{50}$ value of $150 \pm 10 \mu \mathrm{g} / \mathrm{ml}$ compared to other UV treatments undertaken during the study. The $\mathrm{IC}_{50}$ values of Std. Citral and Std. Rutin was found to be $119.67 \pm 0.58$ and $65.44 \pm 1.56 \mu \mathrm{g} / \mathrm{ml}$ respectively.

The essential oil from aerial and sub-aerial parts of UV treated plants exhibited high ABTS scavenging activity with IC50 values ranging from $3.67 \pm 0.29$ to $11.83 \pm 0.29 \mu \mathrm{g} / \mathrm{ml}$. The $\mathrm{IC}_{50}$ values of Std. Citral were $8.97 \pm 0.51$ compared to Std. Rutin showing $15.77 \pm 0.12 \mu \mathrm{g} / \mathrm{ml}$. The comparison of $\mathrm{IC}_{50}$ values between NO and ABTS are tabulated (Table $10)$.

The Total Antioxidant Capacity of essential oils from Control and UV treated plants (aerial and sub-aerial) ranged between 204.64 \pm 0.052 to $738.57 \pm 0.107$ compared with Standard Ascorbic acid. The essential oil from aerial part of UV treated plants showed encouraging results compared to sub aerial and Control plants. Standard Citral exhibited TAC value of $817.08 \pm 0.070$ equivalent to Ascorbic acid. The antioxidant activity of essential oil from aerial and sub aerial part is shown (Table 10).

\section{Anticancer activity:-}

The anticancer activity of essential oils from the Control and UV treated plants were tested by MTT assay, Haemolysis assay, Clonogenic assay, DNA ladder assay and Cell cycle analysis.

During the present investigation, the oil samples (Control, aerial and sub aerial) and Std Citral tested showed dose dependent cytotoxic effect on MCF-7 cells. The $\mathrm{IC}_{50}$ values were determined through non-linear regression analysis using Graph pad Prism-5 software (Table 11 and Fig 9). The essential oil samples and Std. Citral showed IC $_{50}$ values ranging from $151.7-179.8 \mu \mathrm{g} / \mathrm{ml}$. The percentage of haemolysis in essential oils from Control and UV treated plants (aerial and sub-aerial) ranged from $3.10-20.20 \%$ and were expressed between $120-320 \mu \mathrm{g} / \mathrm{ml}$ concentrations (Fig.10)

Based on the results of MTT and Haemolysis assay, the essential oil from aerial part of the Control and UV treated plants possessed potent anticancer activity and thus were further used to study anticancer activities. The essential oil from the Control and UV treated plants showed growth inhibition of $75 \%$ and $80 \%$ in MCF-7 cells (Fig.11). The present study showed that the essential oil from Control plants and UV treated plants showed significant DNA degradation compared to Std DMSO.

The treatment of MCF-7 cells with essential oil obtained from aerial part of UV treated plants at $320 \mu \mathrm{g} / \mathrm{ml}$ concentration showed cell cycle arrest at $25.80 \%$ and $29.96 \%$ in G2/M phase compared to the Control (10.85\%). The result suggests that the essential oil samples obtained from UV treated plants arrested the cell cycle of MCF-7 cells at G2/M phase effectively, thereby inducing the process of apoptosis (Fig $12 \& 13$ )

\section{Discussion:-}

The study showed that there was high variation in essential oil composition in UV treated $C$. flexuosus compared to the Control plants. The new compounds Indole nitrofuryl oxadiazole and 2-tetrahydro furfuryl isothiocyanate obtained during the study showed that UV treatment has acted as stress for the production of new components in the essential oil (Vinutha et al., 2013). These compounds are known to posses wide range of biological activity (Muralikrishna et al., 2014) and require further investigation.

During the study, reduced antibacterial activity was exhibited by essential oil obtained from sub aerial parts of UV treated $C$. flexuosus even at low concentrations $(64 \mu \mathrm{g} / \mathrm{ml})$ when tested against E. coli. Strong antibacterial activity against $S$. typhii was observed when higher concentration of essential oil $(512 \mu \mathrm{g} / \mathrm{ml})$ was used. The major essential oil components present in C. flexuosus oil (Neral and Geranial) was found to be responsible for eliciting strong antibacterial activity against gram negative bacteria (Onawunmi, 1989). The mechanism of the action of essential oil on microorganisms involve damage to cell membrane which affect $\mathrm{pH}$ homeostasis and equilibrium of inorganic 
ions (Cowan, 1999; Burt, 2004) and lead to leakage of cell contents like lipids and proteins (Oyedemi et al.,2009). As the essential oil contain blend of different antimicrobial substances, the risk of pathogenic microorganisms developing resistance is very low (Bakkali et al., 2008; Rahman et al., 2009). This character of essential oil serve as beneficial trait compared to synthetic antimicrobial agents and can be applied for food products for providing food safety with longer shelf life.

In the present investigation on $C$. flexuosus, there was high variation in essential oil content and composition for UV treatment which showed difference in antioxidant activity compared to Control plants. The UV treated essential oil showed highest ABTS scavenging activity $\left(\mathrm{IC}_{50}\right.$ value of $\left.3.83 \pm 0.29 \mu \mathrm{g} / \mathrm{ml}\right)$, TAC $(204.64 \pm 0.052)$ and moderate Nitric Oxide scavenging activity $\left(\mathrm{IC}_{50}\right.$ value of $\left.270 \pm 0.00 \mu \mathrm{g} / \mathrm{ml}\right)$. The UV is known to stimulate the biosynthetic pathway involving dozens of genes (Hanns Frohnmeyer et al., 2003). A short period of UV treatment resulting in higher yields with variation in composition of the essential oil has been reported in many plant species (Nitz et al., 2004). The UV radiation has been reported to affect the composition of essential oil, morphology, total protein and phenol has been reported (Meffei et al., 2011). The extract of $C$. citratus showing low ABTS and Nitric Oxide scavenging activity has been reported (Shan et al., 2005). The antioxidant activity of the essential oils was found to increase with increased concentration of monoterpene hydrocarbons. The monoterpene compounds, Citral and Limonene tested individually exhibited lower antioxidant activity when compared to the total essential oil mixture, which reveal their synergistic effect (Misharina et al., 2008). The mechanism underlying the anticancer activity of essential oils could be due to inhibition of AP-1 transcription factor complex. AP-1 activity has been reported in Hodgkin lymphoma, anaplastic large cell lymphoma, breast cancer, skin tumors, lung cancer and hepatocellular carcinoma. The anticancer activity of the essential oil can be attributed to the terpenoid components present in the oil. The present study conducted on $C$. flexuosus supported the view that the total essential oil could give potent anticancer activity.
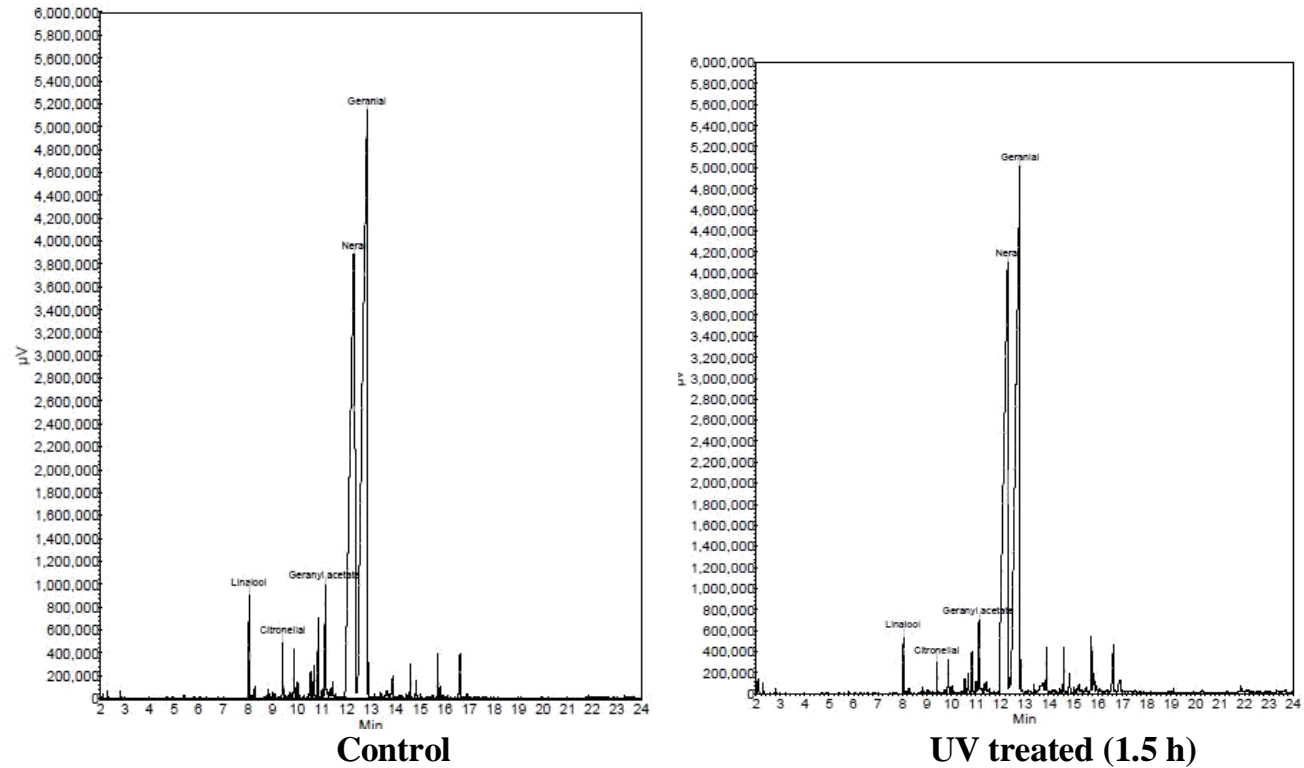

Figure 1 \& 2:- GC-MS analysis of Essential oil from Aerial part 
Table 1:- Chemical composition of the Essential oil from Aerial part (Control)

\begin{tabular}{|c|c|c|}
\hline SL NO & Compound & Area (\%) \\
\hline 1. & 6-Methyl-5- hepten-2-one & $\mathbf{0 . 0 5 \%}$ \\
\hline 2. & Linalool & $0.16 \%$ \\
\hline 3. & á-pinene oxide & $0.04 \%$ \\
\hline 4. & Cis-Limonene oxide & $0.02 \%$ \\
\hline 5. & Z-citral* & $29.85 \%$ \\
\hline 6. & E-citral* & $35.13 \%$ \\
\hline 7. & Geranyl acetate & $0.44 \%$ \\
\hline 8. & Trans-caryophyllene & $0.34 \%$ \\
\hline 9. & Caryophyllene & $\mathbf{0 . 3 3 \%}$ \\
\hline 10. & ò - cadinene & $0.45 \%$ \\
\hline 11. & Caryophyllene oxide & $0.71 \%$ \\
\hline 12. & Farnesol & $0.01 \%$ \\
\hline 13. & Nerol & $2.85 \%$ \\
\hline 14. & 1,7-octadien-3-ol & $10.97 \%$ \\
\hline 15. & Dimethyl-2-cyclopentenone & $0.16 \%$ \\
\hline 16. & Methyldithiocarbazate & $\mathbf{0 . 0 5 \%}$ \\
\hline 17. & 4- Nonanone & $\mathbf{0 . 1 1 \%}$ \\
\hline 20. & Limonene & $0.96 \%$ \\
\hline 22. & Verbenol & $2.77 \%$ \\
\hline 23. & Trans-carveol & $0.07 \%$ \\
\hline 24. & Hexadecanamine & $0.02 \%$ \\
\hline 25. & Fenchone & $0.01 \%$ \\
\hline 26. & Nonanone & $9.44 \%$ \\
\hline 27. & 2-Undecanone & $\mathbf{0 . 0 3 \%}$ \\
\hline 28. & Ethanol octadecadienyloxy $(\mathrm{Z}, \mathrm{Z})$ & $\mathbf{0 . 0 3 \%}$ \\
\hline 29. & Neryl acetate & $0.22 \%$ \\
\hline 30. & Aromadendrene & $0.01 \%$ \\
\hline 31. & Isoindolinone & $\mathbf{0 . 0 8 \%}$ \\
\hline 32. & Phenanthrobenzothiophene & $\mathbf{0 . 0 3 \%}$ \\
\hline 33. & Undecene & $\mathbf{0 . 0 3 \%}$ \\
\hline 34. & Humulene epoxide & $\mathbf{0 . 0 3 \%}$ \\
\hline 36. & Phytol & $0.05 \%$ \\
\hline 37. & Neoisolongifolene & $\mathbf{0 . 0 5 \%}$ \\
\hline 38. & Uvidin A & $0.02 \%$ \\
\hline
\end{tabular}

*Isomers of citral

Table 2:- Chemical composition of the Essential oil from Aerial part (UV treatment-1.5 h).

\begin{tabular}{|c|c|c|}
\hline SL NO & COMPOUND & AREA \% \\
\hline 1. & Linalyl acetate & $\mathbf{0 . 0 7}$ \\
\hline 2. & $\mathbf{2 , 6 - N o n a d i e n a l , 3 , 7 - d i m e t h y l - ~}$ & $\mathbf{0 . 0 1}$ \\
\hline 3. & (+)-9-O-Demethylhomolycorine & $\mathbf{0 . 3 3}$ \\
\hline 4. & Geranyl nitrile & $\mathbf{0 . 3 3}$ \\
\hline 5. & Ethanone & $\mathbf{0 . 5 4}$ \\
\hline 6. & Z-limonene-1,2-epoxide & $\mathbf{5 2 . 8 1}$ \\
\hline 7. & E-Citral* & $\mathbf{3 1 . 9 8}$ \\
\hline 8. & Z-Citral* & $\mathbf{0 . 9 7}$ \\
\hline 9. & trans-Verbenone & 5.68 \\
\hline 10. & Verbenol & $\mathbf{0 . 0 8}$ \\
\hline 11. & cis-Carvyl acetate & $\mathbf{0 . 0 4}$ \\
\hline 12. & cis-Carveol & $\mathbf{0 . 0 2}$ \\
\hline 13. & trans-Resveratrol & $\mathbf{6 . 6 4}$ \\
\hline 14. & Mefenorex & \\
\hline
\end{tabular}




\begin{tabular}{|c|c|c|}
\hline 15. & trans-carvyl acetate & $\mathbf{6 . 6 4}$ \\
\hline 16. & 2-Undecanone & $\mathbf{0 . 0 2}$ \\
\hline 17. & Rhombifolin & $\mathbf{0 . 0 2}$ \\
\hline 18. & Geranyl acetate & $\mathbf{0 . 0 6}$ \\
\hline 19. & Neryl acetate & $\mathbf{0 . 0 4}$ \\
\hline 20. & trans-Caryophyllene & $\mathbf{0 . 0 9}$ \\
\hline 21. & trans-ã-cadinene & $\mathbf{0 . 2 9}$ \\
\hline 22. & à-Amorphene & $\mathbf{0 . 1 3}$ \\
\hline 23. & Torreyol & $\mathbf{0 . 0 2}$ \\
\hline 24. & Spathulanol & $\mathbf{0 . 0 2}$ \\
\hline 25. & Cubenol & $\mathbf{0 . 0 2}$ \\
\hline 26. & Isolongifolan-8-ol & $\mathbf{0 . 0 2}$ \\
\hline 27. & Caryophyllene oxide & $\mathbf{0 . 3 1}$ \\
\hline 28. & Longifolenaldehyde & $\mathbf{0 . 2 1}$ \\
\hline 29. & Humulene oxide & $\mathbf{0 . 0 4}$ \\
\hline 30. & (+)-(R)-à-Ionol & $\mathbf{0 . 0 2}$ \\
\hline 31. & 5-Isocedranol & $\mathbf{0 . 0 2}$ \\
\hline 32. & Farnesyl acetate & $\mathbf{0 . 0 2}$ \\
\hline 33. & Alloaromadendrenoxide-(1) & $\mathbf{0 . 0 2}$ \\
\hline 34. & Isoaromadendrene epoxide & $\mathbf{0 . 0 2}$ \\
\hline 35. & Longipinocarveol, trans- & $\mathbf{0 . 0 2}$ \\
\hline 36. & Neophytadiene & $\mathbf{0 . 0 1}$ \\
\hline 37. & Linoleic acid methylsilyl ester & $\mathbf{0 . 0 1}$ \\
\hline 38. & Urs-12-en-28-al & $\mathbf{0 . 0 1}$ \\
\hline 39. & Ethyl geranate & $\mathbf{0 . 0 1}$ \\
\hline
\end{tabular}

*Isomers of citral
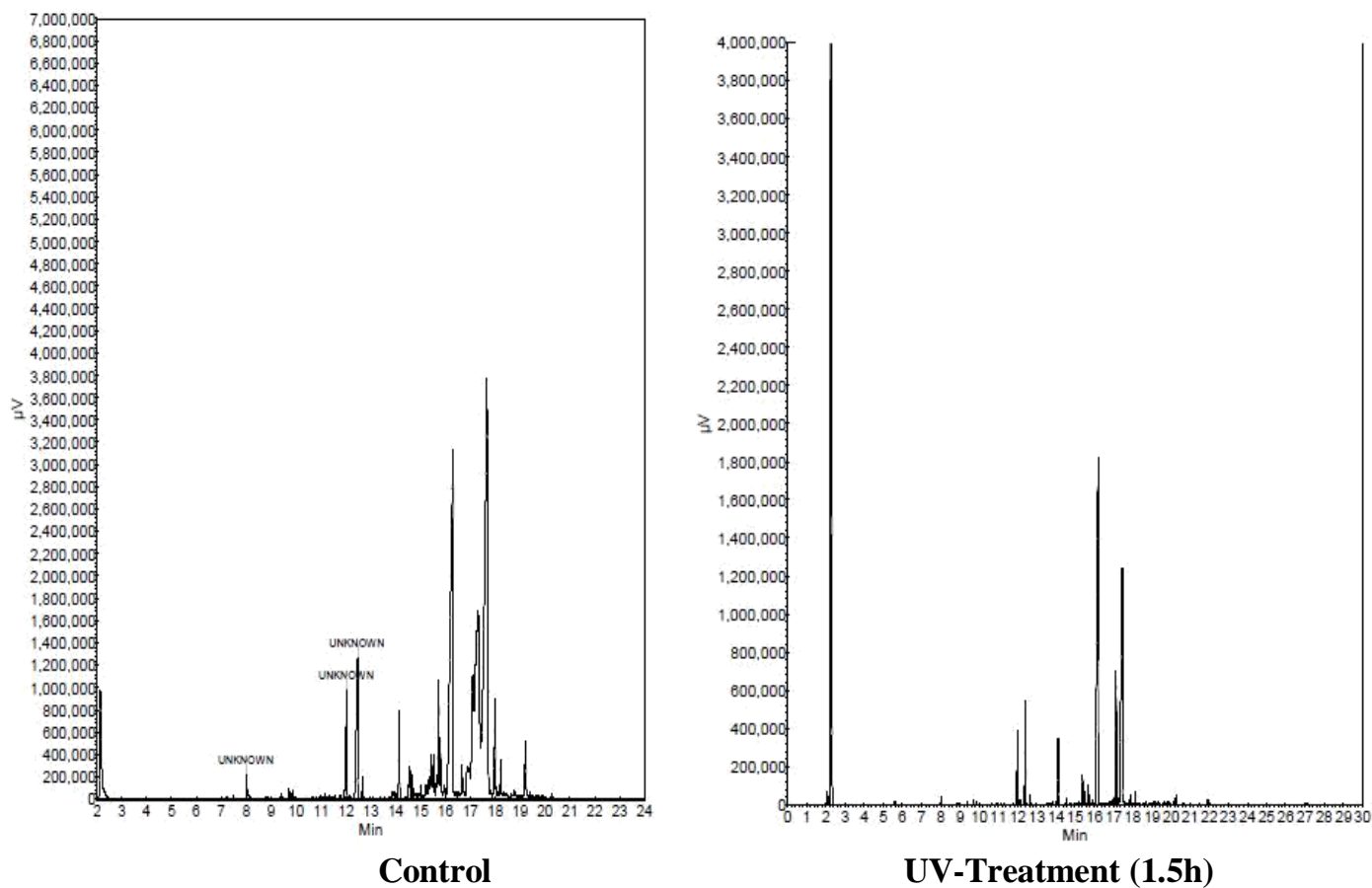

Figure 3 \& 4:- GC-MS analysis of essential oil from Sub-Aerial part. 
Table 3:- Chemical composition of the Essential oil from Sub-Aerial part (Control)

\begin{tabular}{|c|c|c|}
\hline SL NO & COMPOUND & AREA \% \\
\hline 1. & Elemene & $1.04 \%$ \\
\hline 2. & Juniper camphor & 1.12 \\
\hline 3. & ò - terpinene & $\mathbf{0 . 0 2}$ \\
\hline 4. & Elemol & 14.16 \\
\hline 5. & E-citral* & 22.35 \\
\hline 6. & Z-citral* & 8.12 \\
\hline 7. & á-Eudesmol & 17.82 \\
\hline 8. & -cadinene & 1.88 \\
\hline 9. & (E)-2,3-Epoxyoctan-1-ol & 0.08 \\
\hline 10. & 1-[2H3] Methoxyindole & 0.08 \\
\hline 11. & 9-oxabicyclo[6.1.0]non-6-en-2-one & 0.16 \\
\hline 12. & 2-Heptanone,6-methyl & 0.06 \\
\hline 13. & á-Elemene & 1.04 \\
\hline 14. & Junipene & 1.36 \\
\hline 15. & Adrenalone & $\mathbf{0 . 0 2}$ \\
\hline 16. & Pulegone & 0.24 \\
\hline 17. & Dihydro-3-isopropyl-8a-methylazulene & 11.08 \\
\hline 18. & (-)-(10R)-Hydroxyallo aromadendrane & 1.12 \\
\hline 19. & Polysterene & 0.20 \\
\hline 20. & Herquinone & 0.04 \\
\hline 21. & (3-Fluoro-5-bromophenoxy)amine & 0.04 \\
\hline 22. & Cyclopent-1-enyl-1-methylethyl)-cyclopentanone & 0.04 \\
\hline 23. & Nonanone & 0.08 \\
\hline 24. & Cadinene & 0.68 \\
\hline 25. & ä-cadinene & 1.88 \\
\hline 26. & Octahydropentalene & 0.26 \\
\hline 27. & 8â-Drimanol & 1.20 \\
\hline 28. & Brasudol & 0.20 \\
\hline 29. & Naphthalenetriol & 0.92 \\
\hline 30. & Enediol & 0.02 \\
\hline 31. & Unknown & 0.68 \\
\hline
\end{tabular}

*Isomers of citral.

Table 4:- Chemical composition of the Essential oil from Sub Aerial part (UV treatment-1.5h)

\begin{tabular}{|c|c|c|}
\hline SL NO & COMPOUND & AREA \% \\
\hline 1. & E-citral* & 3.92 \\
\hline 2. & Z-citral* & 1.40 \\
\hline 3. & Caryophyllene & $\mathbf{0 . 0 3}$ \\
\hline 4. & Limonene oxide & $\mathbf{0 . 7 4}$ \\
\hline 5. & Isophorol & 1.35 \\
\hline 6. & trans-Caryophyllene & $\mathbf{0 . 1 2}$ \\
\hline 7. & Bicyclogermacrene, & $\mathbf{0 . 0 3}$ \\
\hline 8. & ç-Elemene, & $\mathbf{0 . 0 5}$ \\
\hline 9. & Germacrene B & $\mathbf{0 . 0 9}$ \\
\hline 10. & Bicycloelemene & $\mathbf{0 . 1 2}$ \\
\hline 11. & à-Fluoromethyl chalcone & $\mathbf{0 . 8 1}$ \\
\hline 12. & Veridiflorol, & $\mathbf{0 . 0 5}$ \\
\hline 13. & Ledol & $\mathbf{0 . 0 5}$ \\
\hline 14. & Spathulanol & $\mathbf{0 . 0 5}$ \\
\hline 15. & Sabinene & $\mathbf{0 . 1 9}$ \\
\hline 16. & Cyclofenchene & $\mathbf{0 . 1 9}$ \\
\hline 17. & Indol-nitrofuryl-oxadiazole & $\mathbf{5 9 . 7 7}$ \\
\hline
\end{tabular}




\begin{tabular}{|c|c|c|}
\hline 18. & Menthol & 1.48 \\
\hline 19. & 2-Tetrahydrofurfuryl isothiocyanate & 32.61 \\
\hline 20. & Caryophyllene oxide, & 0.15 \\
\hline 21. & trans-Farnesal & 0.17 \\
\hline 22. & Longifolenaldehyde & 1.89 \\
\hline 23. & Geranylgeraniol & 2.34 \\
\hline 24. & Anisaldehyde & $\mathbf{0 . 0 2}$ \\
\hline 25. & Alloaromadendrane & $\mathbf{0 . 1 5}$ \\
\hline 26. & 2-Nitrosoguaiacol & $\mathbf{0 . 0 6}$ \\
\hline 27. & Rosifoliol & $\mathbf{0 . 0 4}$ \\
\hline 28. & 2-Naphthalenemethan ol, & $\mathbf{0 . 0 3}$ \\
\hline 29. & á-Eudesmol & $\mathbf{0 . 0 9}$ \\
\hline 30. & Guaidiol & $\mathbf{0 . 0 2}$ \\
\hline
\end{tabular}

*Isomers of citral.

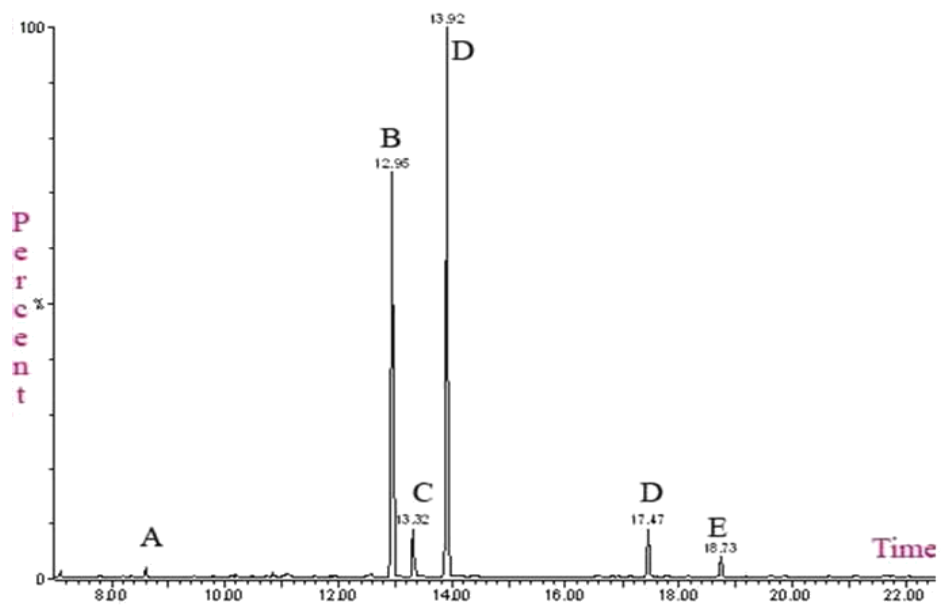

Figure 5:- Gas chromatogram of Std. Citral

Table 5:- Minimum inhibitory concentration (MIC) of the Essential oil against Escherichia coli

\begin{tabular}{|l|l|l|l|l|l|l|l|}
\hline Dilution & Std Citral & C (A) & UV(A) & C (SA) & UV(SA) & Ciproflaxacin & Dilution \\
\hline 512 & 84.8 & 63.7 & 61.0 & 50.04 & 100.0 & 100.0 & 128 \\
\hline 256 & 48.3 & 35.2 & 61.6 & 11.9 & 100.0 & 100.0 & 64 \\
\hline 128 & 30.3 & 15.8 & 30.9 & 0.0 & 100.0 & 100.0 & 32 \\
\hline 64 & 22.1 & 0.0 & 16.9 & 0.0 & 100.0 & 100.0 & 16 \\
\hline 16 & 10.8 & 0.0 & 0.0 & 0.0 & 36.0 & 100.0 & 8 \\
\hline 4 & 0.0 & 0.0 & 0.0 & 0.0 & 4.5 & 100.0 & 4 \\
\hline 1 & 0.0 & 0.0 & 0.0 & 0.0 & 6.1 & 100.0 & 2 \\
\hline 0 & 0.0 & 0.0 & 0.0 & 0.0 & 0.0 & 0.0 & 1 \\
\hline
\end{tabular}

Where C (A) - Control (Aerial), UV (A) - UV treatment (Aerial), C (SA) - Control (Sub-Aerial), UV (SA) UV treatment (Sub- Aerial).

Table 6:- Minimum Inhibitory Concentration (MIC) of the Essential oil against Salmonella typhii

\begin{tabular}{|l|l|l|l|l|l|l|l|}
\hline Dilution & Std Citral & C (A) & UV(A) & C (SA) & UV(SA) & Ciproflaxacin & Dilution \\
\hline 512 & 1.91 & 0.00 & 0.00 & 13.16 & 100.0 & 100.0 & 128 \\
\hline 256 & 0.00 & 0.00 & 0.00 & 7.61 & 89.35 & 100.0 & 64 \\
\hline 128 & 0.00 & 0.00 & 0.00 & 0.00 & 46.60 & 100.0 & 32 \\
\hline 64 & 0.00 & 0.00 & 0.00 & 0.00 & 20.27 & 100.0 & 16 \\
\hline 16 & 0.00 & 0.00 & 0.00 & 0.00 & 0.00 & 100.0 & 8 \\
\hline 4 & 0.00 & 0.00 & 0.00 & 0.00 & 0.00 & 100.0 & 4 \\
\hline 1 & 0.00 & 0.00 & 0.00 & 0.00 & 0.00 & 100.0 & 2 \\
\hline 0 & 0.00 & 0.00 & 0.00 & 0.00 & 0.00 & 0.00 & 1 \\
\hline
\end{tabular}


Where C (A) - Control (Aerial), UV (A) - UV treatment (Aerial), C (SA) - Control (Sub-Aerial), UV (SA) - UV treatment (Sub- Aerial).

Table 7:- Minimum Inhibitory Concentration (MIC) of the Essential oil against Shigella dysenteriae

\begin{tabular}{|l|l|l|l|l|l|l|l|}
\hline Dilution & Std Citral & C (A) & UV(A) & C (SA) & UV(SA) & Ciproflaxacin & Dilution \\
\hline 512 & 41.80 & 35.74 & 28.22 & 0.00 & 100.0 & 100.0 & 128 \\
\hline 256 & 35.88 & 23.25 & 28.81 & 4.32 & 95.76 & 100.0 & 64 \\
\hline 128 & 2.02 & 5.01 & 7.53 & 0.00 & 94.76 & 100.0 & 32 \\
\hline 64 & 1.49 & 5.18 & 3.84 & 3.29 & 41.06 & 100.0 & 16 \\
\hline 16 & 3.80 & 5.51 & 0.00 & 7.43 & 0.00 & 98.95 & 8 \\
\hline 4 & 2.68 & 4.22 & 0.00 & 4.79 & 0.00 & 72.78 & 4 \\
\hline 1 & 3.15 & 0.71 & 0.00 & 1.01 & 0.00 & 21.58 & 2 \\
\hline 0 & 0.00 & 0.00 & 0.00 & 0.00 & 0.00 & 0.00 & 1 \\
\hline
\end{tabular}

Where C (A) - Control (Aerial), UV (A) - UV treatment (Aerial), C (SA) - Control (Sub-Aerial), UV (SA) - UV treatment (Sub- Aerial).

Table 8:- Minimum Inhibitory Concentration (MIC) of the Essential oil against Pseudomonas aeruginosa

\begin{tabular}{|l|l|l|l|l|l|l|l|}
\hline Dilution & Std Citral & C (A) & UV(A) & C (SA) & UV(SA) & Ciproflaxacin & Dilution \\
\hline 512 & 16.12 & 20.37 & 15.12 & 13.16 & 100.0 & 100.0 & 128 \\
\hline 256 & 3.01 & 8.07 & 15.12 & 13.11 & 96.48 & 100.0 & 64 \\
\hline 128 & 0.00 & 1.36 & 7.68 & 19.00 & 68.84 & 100.0 & 32 \\
\hline 64 & 0.00 & 1.82 & 0.00 & 9.29 & 37.15 & 100.0 & 16 \\
\hline 16 & 0.00 & 1.36 & 0.00 & 4.58 & 13.25 & 100.0 & 8 \\
\hline 4 & 0.00 & 1.32 & 0.00 & 2.46 & 4.76 & 100.0 & 4 \\
\hline 1 & 0.00 & 0.00 & 0.00 & 0.94 & 0.00 & 100.0 & 2 \\
\hline 0 & 0.00 & 0.00 & 0.00 & 0.00 & 0.00 & 0.00 & 1 \\
\hline
\end{tabular}

Where C (A) - Control (Aerial), UV (A) - UV treatment (Aerial), C (SA) - Control (Sub-Aerial), UV (SA) - UV treatment (Sub- Aerial).

Table 9:- Comparison of Minimum Inhibitory Concentration $(\mu \mathrm{g} / \mathrm{ml})$ against tested bacteria

\begin{tabular}{|c|c|c|c|c|c|c|}
\hline Compound organism & Citral & C(A) & UV(A) & C(SA) & UV(SA) & Ciproflaxin \\
\hline E. coli & 256 & 512 & 256 & 512 & 32 & $<1$ \\
\hline P.aerugenosa & $>512$ & $>512$ & $>512$ & $>512$ & 128 & $<1$ \\
\hline S. typhii & $>512$ & $>512$ & $>512$ & $>512$ & 128 & $<1$ \\
\hline S.dysenteriae & $>512$ & $>512$ & $>512$ & $>512$ & 128 & $<1$ \\
\hline
\end{tabular}

Where C (A) - Control (Aerial), UV (A) - UV treatment (Aerial), C (SA) - Control (Sub-Aerial), UV (SA) - UV treatment (Sub- Aerial).

Table 10:- Antioxidant activity of the Essential oil.

\begin{tabular}{|l|l|l|l|}
\hline \multirow{2}{*}{ Essential oil } & \multicolumn{2}{|c|}{ IC $_{\mathbf{5 0}}$ value } & \\
\cline { 2 - 4 } & Nitric oxide & ABTS & TAC *a $^{\mathbf{a}}$ \\
\hline Control (A) & $270 \pm 0.00$ & $9.0 \pm 1.0$ & $647.94 \pm 0.119$ \\
\hline & & & \\
\hline UV-1.5 h (A) & $310 \pm 10$ & $3.83 \pm 0.29$ & $738.57 \pm 0.107$ \\
\hline Control (SA) & $663.33 \pm 11.55$ & $57.0 \pm 1.7$ & $204.64 \pm 0.052$ \\
\hline UV-1.5 h Citral (SA) & $393.33 \pm 5.77$ & $7.5 \pm 0.5$ & $647.94 \pm 0.119$ \\
\hline UV-1.0 h Geranial (SA) & $446.67 \pm 5.77$ & $11.83 \pm 0.29$ & $208.19 \pm 0.010$ \\
\hline UV-0.25 h Neral (SA) & $150 \pm 10$ & $3.67 \pm 0.29$ & ND \\
\hline Std Citral & $119.67 \pm 0.58$ & $8.97 \pm 0.51$ & $817.08 \pm 0.070$ \\
\hline Standard & $65.44 \pm 1.56$ (Rutin) & $15.77 \pm 0.12$ (Rutin) & acid) \\
\hline & & & \multicolumn{2}{c}{ (Ascorbic } \\
\hline & & & \\
\hline
\end{tabular}


A-Aerial, SA - Sub Aerial, *a - total antioxidant capacity expressed as mg equivalent of ascorbic acid per gm of dry weight

Table 11:- Non-linear regression analysis showing $\mathrm{IC}_{50}$ values of Essential oil (MTT assay)

\begin{tabular}{|c|c|c|c|c|c|}
\hline Log(inhibitor) vs response Best-fit value & Citral & E1 & E2 & E3 & E4 \\
\hline Bottom & 142.7 & 148.4 & 150.2 & 134.4 & 155.3 \\
\hline Top & -10.26 & -8.193 & -4.880 & -8.209 & -8.254 \\
\hline $\operatorname{Log~IC} C_{50}$ & 2.181 & 2.207 & 2.216 & 2.255 & 2.209 \\
\hline $\mathrm{IC}_{50}$ & 151.7 & 161.0 & 164.4 & 179.8 & 161.9 \\
\hline
\end{tabular}

Where E1 - Control (aerial), E2 - UV Treated (aerial), E3 - Control (sub-aerial) and E4 - UV treated (sub-aerial).

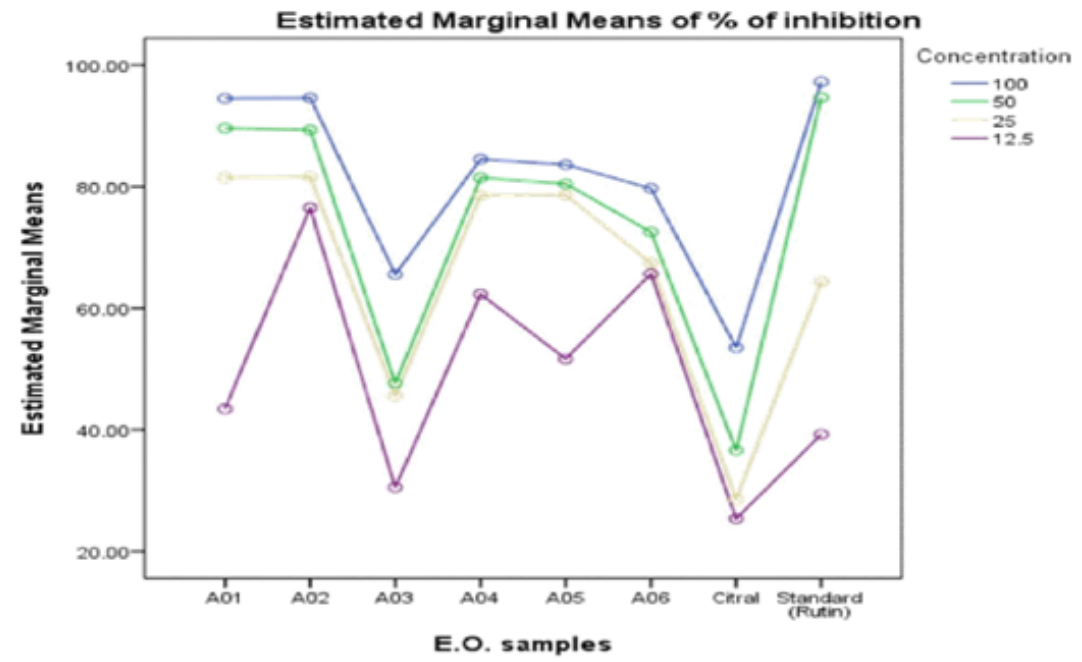

Figure 6: Variation in percentage inhibition for $\mathrm{NO}$ and $\mathrm{ABTS}$ assay. Where, $\mathrm{A} 01$ Control Aerial, A02 - UV-1.5 h (A), A03 - Control Sub Aerial, A04 - UV-1.5 h (SA)

A05 - UV-1.0 h (SA), A06 - UV-0.25 h (SA)

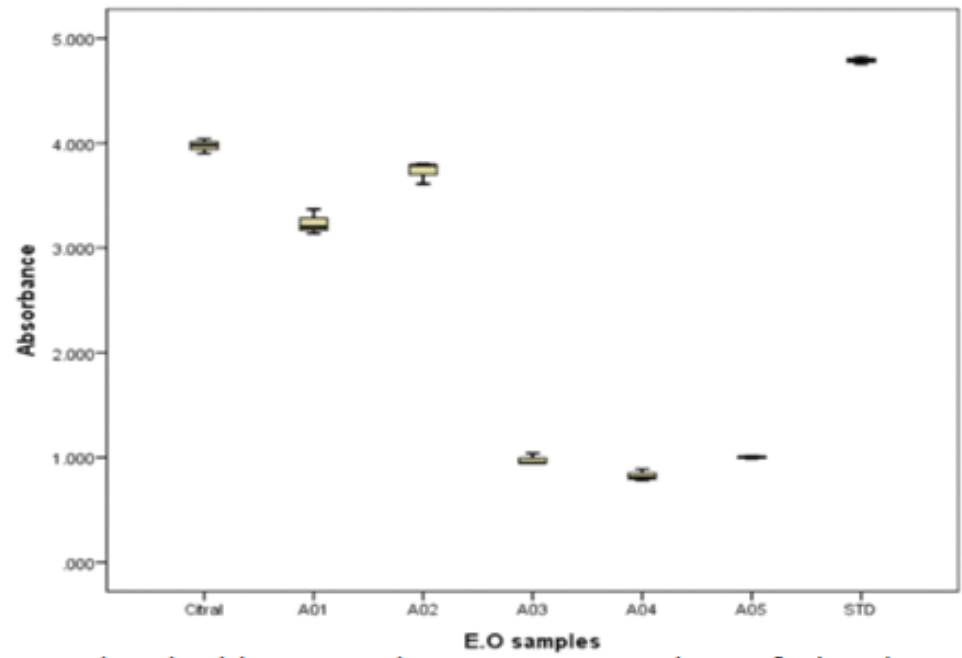

Figure 7:Total antioxidant capacity assay: Comparison of Absorbance in the test samples Where, A01 - Control Aerial, A02 - UV-1.5 h (A), A03 - Control Sub Aerial, A04 - UV-1.5 h (SA) A05 - UV-1.0 h (SA), A06 - UV-0.25 h (SA) 


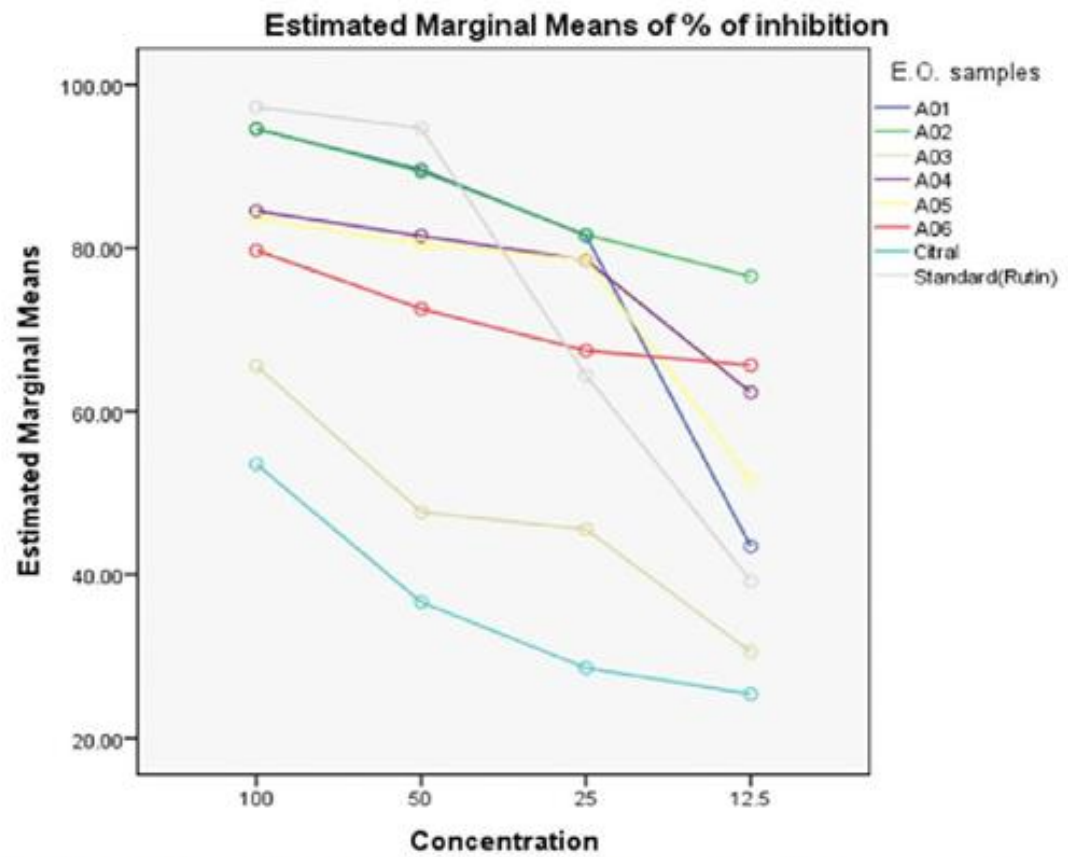

Figure 8: Total Antioxidant Capacity Assay: Marginal means of percentage inhibition. Where, A01 - Control Aerial, A02 - UV-1.5 h (A), A03 - Control Sub Aerial, A04 - UV-1.5 h (SA) A05 - UV-1.0 h (SA), A06 - UV-0.25 h (SA)

\section{Cytotoxicity activity ---IC 50 Determinations}

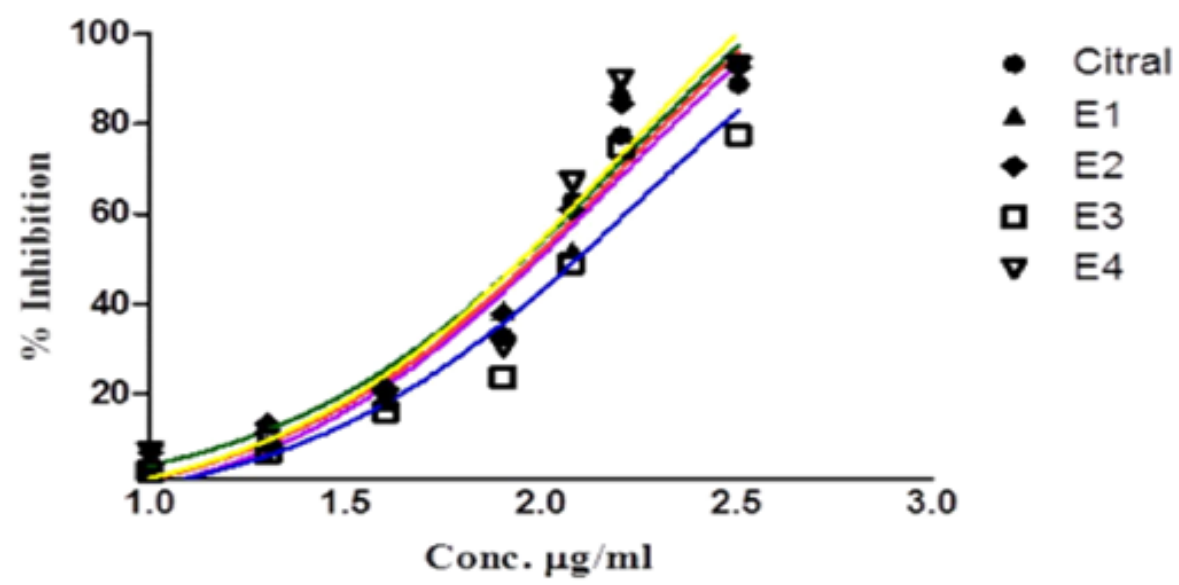

Figure 9: Cytotoxic activity of the Essential oil Where, E1 - control (Aerial), E2 - UV (Aerial), E3 - Control (Sub Aerial), E4 - UV (Sub Aerial). 


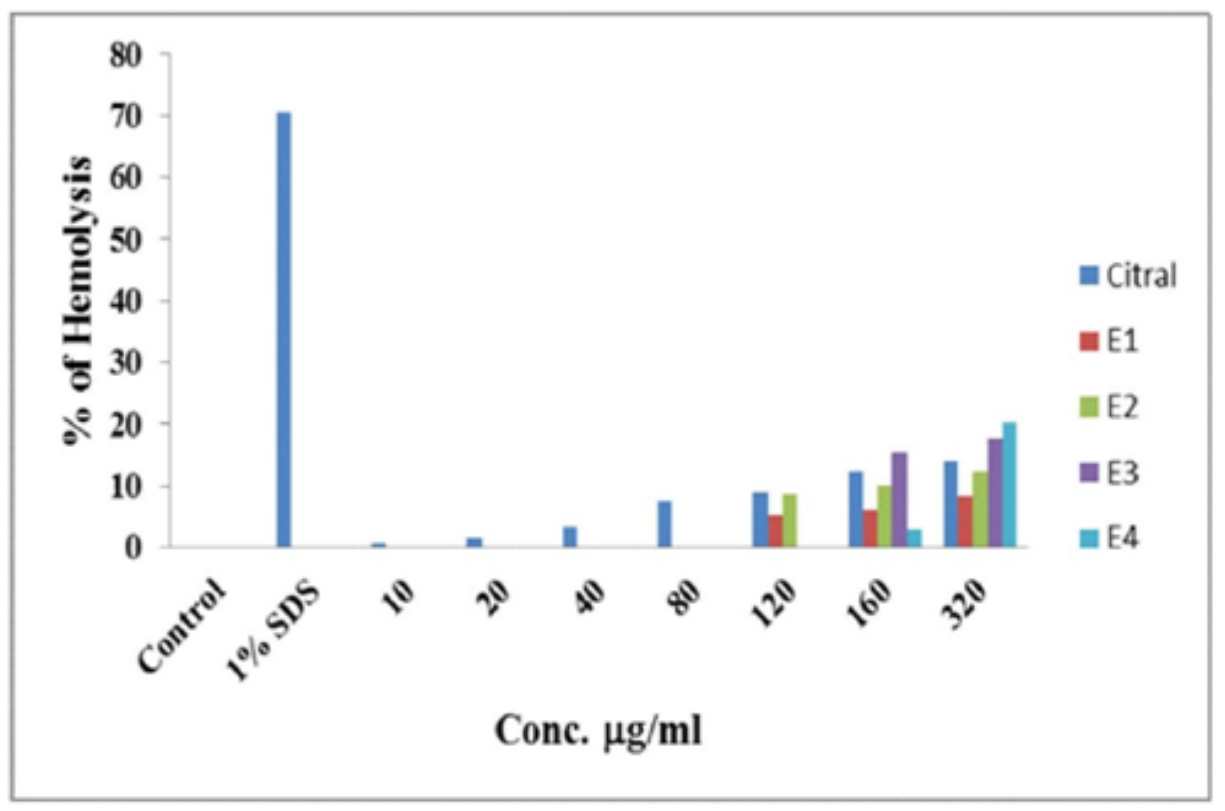

Figure 10: Percentage of Haemolysis of the Essential oil

Where E1 - control (Aerial), E2 - UV (Aerial), E3 - Control (Sub Aerial), E4 - UV (Sub Aerial).

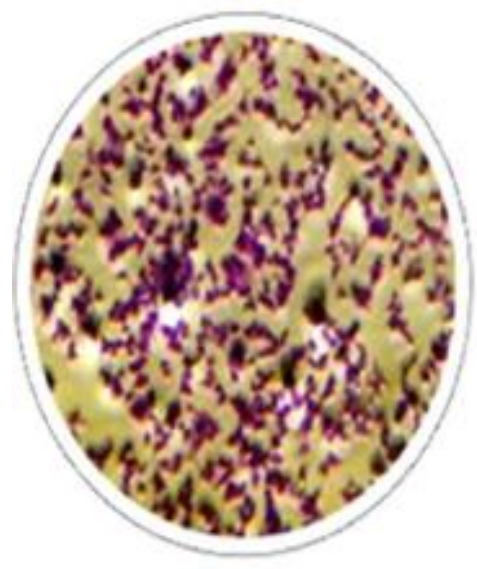

Std

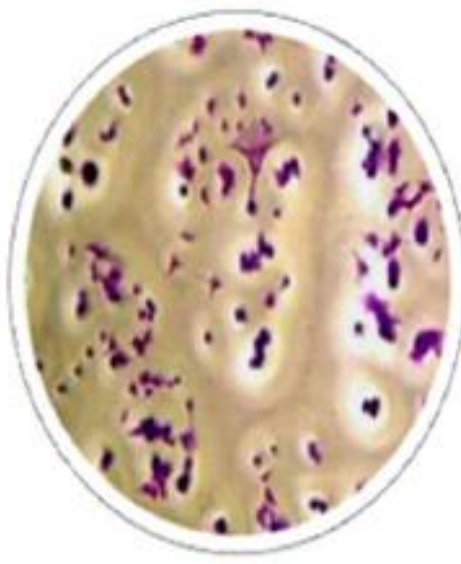

Control

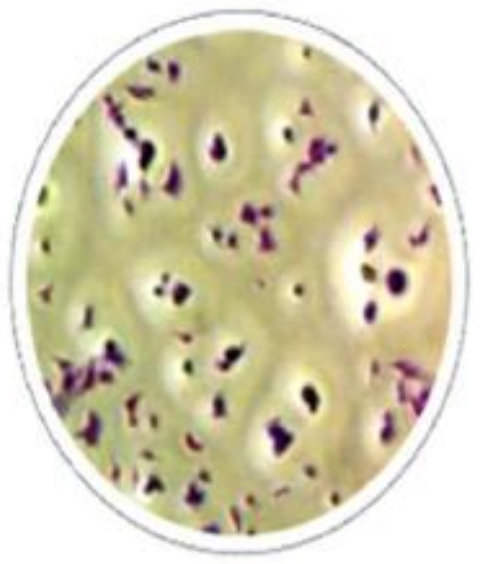

UV Treatment

Figure 11: Clonogenic Assay of Essential oils 


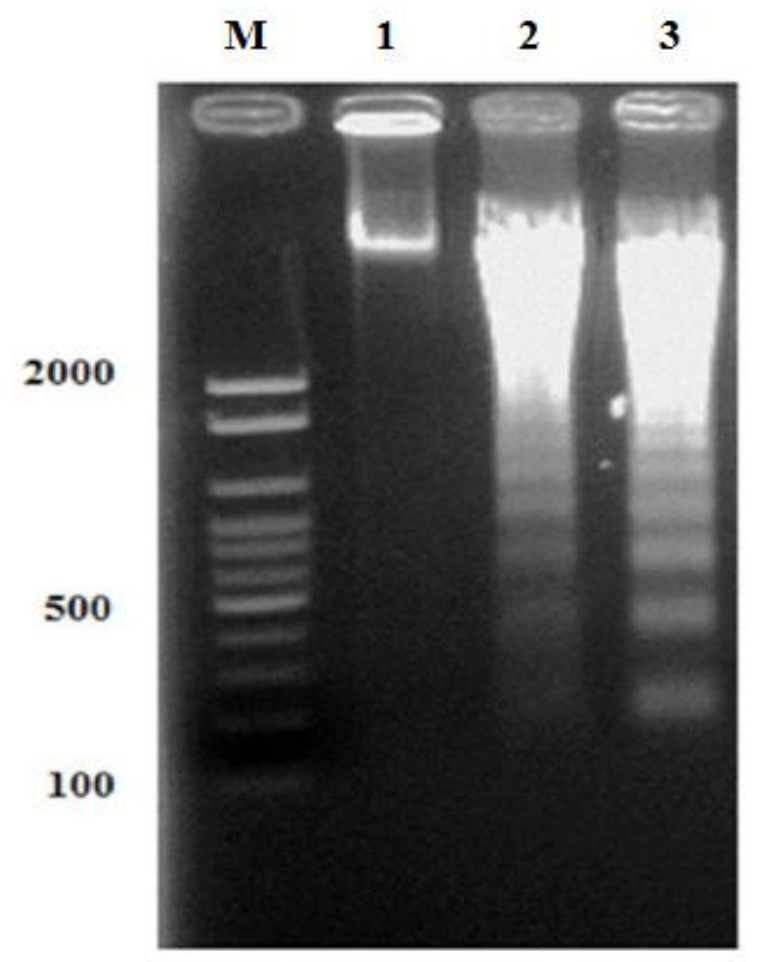

Figure 12: DNA fragmentation of $\mathrm{MCF}-7$ cells treated with Essential oil Where, M-DNA Marker, 1-Control (0.1\% DMSO), 2-Control (Aerial), 3-UV (Aerial) 

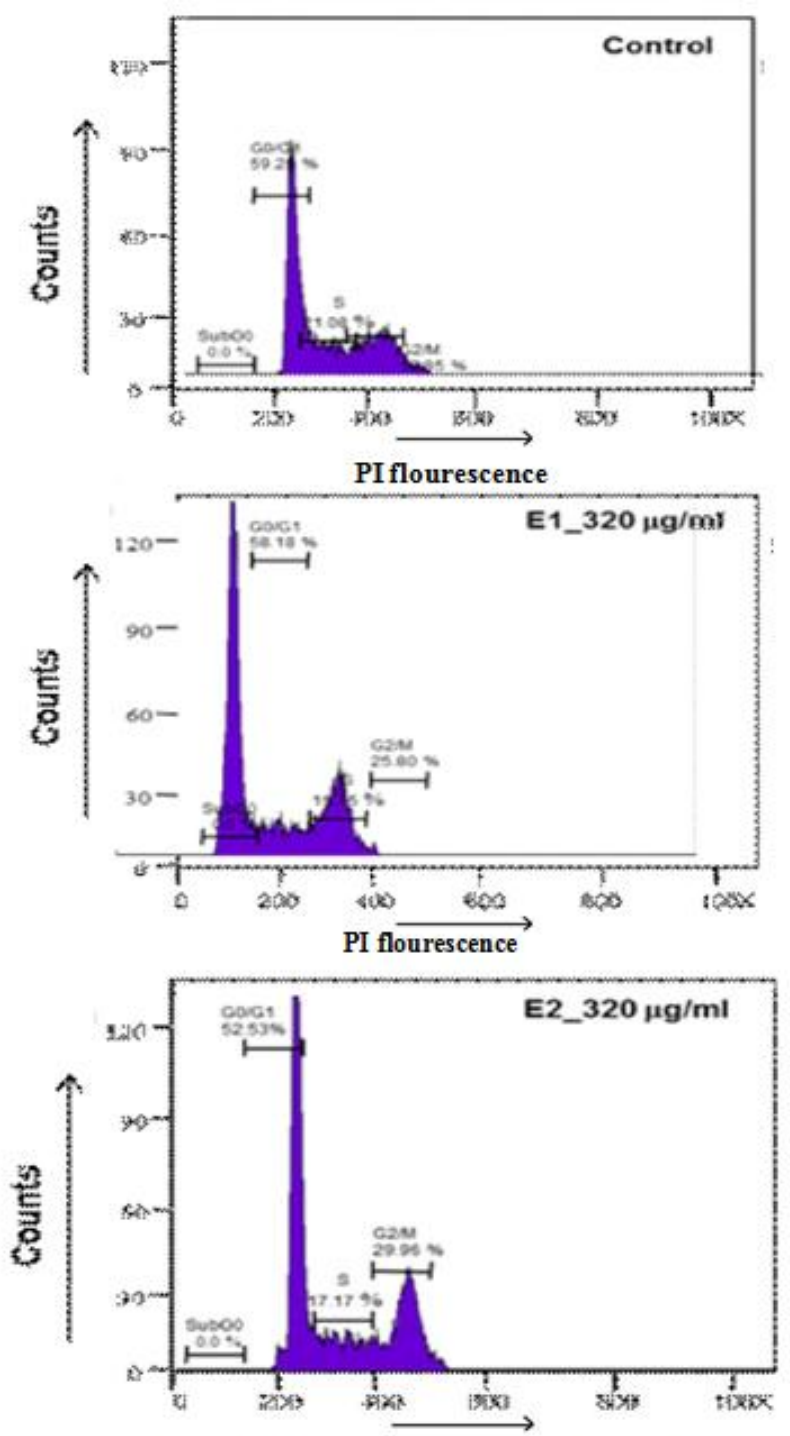

Figure 13: Cell cycle analysis in MCF-7 cells E1 and E2 (Essential oil from Aerial and sub Aerial parts from UV treatment)

\section{Bibliography:-} comparison with Control

1. Adams RP. 2007. Identification of essential oil components by gas Chromatography / mass spectrometry. Carol Stream, IL, USA: Allured Publishing Co.

2. Adinarayana G, Rahul G, Ravi Kiran, Syamsundar KV and Rajeshwara Rao BR, 2012. Evaluation of antimicrobial Potential of Field Distilled and Water-Soluble Essential Oils of Cymbopogon flexuosus. Journal of Pharmacognosy. Vol 3(2): 142-146

3. Arnao, M.B., Cano, A. and Acosta, M., 2001. The hydrophilic and lipophilic contribution to total antioxidant activity. Food Chemistry. Vol 73: 239-244

4. Bakkali, F., Averbeck, S., Averbeck, D and Idaomar, M. 2008. Biological effects of essential oils - a review. Food Chem Toxicol. Vol 46: 446-475

5. Burt S., 2004.Essential oils: Their antibacterial properties and potential applications in foods. Int. J. Food Microbiol. Vol 94: 223-253

6. Cowan, M.M., 1999. Plant products as antimicrobial agents. Clin. Microbiol. Rev. 564-582.

7. Chandrashekar K S and Prasanna K S 2010. Analgesic and Anti-inflammatory activities of the essential oil from Cymbopogon flexuosus. Pharmacognosy Journal. Vol 2: 23-26

8. S. C. Chao, D. G. Young, and C. J. Oberg. 2000. Screening for inhibitory activity of essential oils on selected 
bacteria, fungi and viruses. Journal of Essential Oil Research. Vol. 12 (5): 639-649

9. Griess P 1879. Bemerkungen zu der Abhandlung der HH Weselsky and Benedikt. Ueber einige azoverbindungen chem. Ber. Vol 12: 426-428

10. Garrat DC 1964. The quantitiative Analysis of Drugs, 3rd Ed. Chapman and Hall Ltd., Japan. 456-58

11. Grace O. Onawunmi 1989. Evaluation of the antimicrobial activity of citral. Vol 9(3): 105-108

12. Hanns Frohnmeyer and Dorothee Staiger 2003. Ultraviolet-B Radiation-Mediated Responses in Plants. Balancing Damage and Protection, Plant Physiology.133 no.4 :1420-1428

13. Joy PP, Baby P Skaria, Samuel Mathew, Gracy Mathew and Ancy Joseph, 2006. Lemongrass: The fame of Cochin. Indian J. Arecanut, Spices and Medicinal Plants. Vol 8(2): 55-64.

14. Lawrence B. M. 1984. A review of the world production of essential oils. Perfumer and Flavorist. Vol 10(5): 116

15. S.Muralikrishna. 2014. Synthesis of 1,3,4 Oxadiazole derivatives containing Indole moiety bearing Thiazolidinone and Anti-inflamatory activity of Thiazolidinone. International Journal of ChemTech Research. Vol. 6(1): 183-194

16. Mohd Fazrullah Innsan, M. Hairul Shahril, M. S. Samihah, O. Siti Asma, S. Mat Radzi, A. K. Abd Jalil and M. N. Hanina. 2011. Pharmacodynamic properties of essential oils from Cymbopogon species. Vol.5(24): 2676 2679

17. Mojca S, Petra K, Majda H, Andreja RH, Marjana S and Zeljko KP. 2005 Proanthocyanidins, flavones and flavonols in some plant materials and their antioxidant activities. Food Chem. Vol 89:191-19

18. M. Maffei and S. Scannerini 2011. UV-B Effect on Photomorphogenesis and Essential Oil Composition in Peppermint (Mentha piperita L.), Journal of essential oil research. Vol 10: 523-529

19. Milchunas DG, King JY, Mosier AR, Moore JC and Morgan JA. 2004. UV Radiation Effects on Plant Growth and Forage Quality in a Shortgrass Steppe Ecosystem, Photochemistry and photobiology. Vol 79: 404-410.

20. Misharina TA, Terenina MB and Krikunova NI 2009. Antioxidant Properties of Essential Oils. Applied Biochemistry and Microbiology. Vol 45(6): 642-647

21. Nenadis N, Wang LF, Tsimidou M and Zhang HY 2004. Estimation of scavenging activity of phenolic compound using the ABTS + assay. J. Agric. Food Chem. Vol 52(15):4669-4674

22. Nayak S, Debata BK, Srivastava VK and Sangwan NS 2003. Evaluation of agronomically useful somaclonal variants in Jamrosa (a hybrid Cymbopogon) and detection of genetic changes through RAPD. Plant Sci. Vol 164:1029-1035.

23. Nitz G M and Schnitzler W H. 2004. Effect of PAR and UV-B Radiation on the quality and quantity of the essential oil in Sweet basil (Ocimum basilicum L.), Acta Horticulture (ISHS) 659: 375-381.

24. Oyedemi s O, A I Okoh, L V Mabinya, G Pirochenva and A J Afolayan. 2009. The proposed mechanism of bactericidal action of eugenol, $\gamma$-terpineol and $\gamma$-terpinene against Listeria monocytogens, Streptococcus pyogenes, Proteus Vulgaris and Escherichia coli. African Journal Biotechnol. Vol 8: 1280-1286

25. Rahman A and kang S C. 2009. Invitro control of food borne and food spoilage bacteria by essential oil and ethanol extracts of Lonicera japonica Thunb. Food Chemistry. Vol 116: 670-675

26. Sahoo, J. and Mohanty B. 2004. Indigenous Methods of Preserving Manuscripts: A Overview; The Orissa Historical Research Journal (OHRJ), Vol. XLVII, No. 3: 28-32.

27. Sharma PR, Mondhe DM, Muthiah S, Pal HC, Shahi AK, Saxena AK and Qazi GN, 2009. Anticancerous activity of an essential oil from Cymbopogon flexuosus Chem. Biol. Interact 179: 160-168

28. Shan B, Cai YZ, Sun M and Corke H.2005. Antioxidant capacity of 26 spice extracts and characterization of their phenolic constituents. J Agric Food Chem 53:7749-7759.

29. Tsormpatsidis, E., R.G.C. Henbest, N.H. Battey and P. Hadely. 2010. The influence of ultraviolet radiation on growth, photosynthesis and phenolic levels of green and red lettuce: potential for exploiting effects of ultraviolet radiation in a production system. Annals of Applied Biol. Vol 156: 357-366.

30. Uniyal RC, Uniyal and MR, Jain P 2000. Cultivation of medicinal plants in India. A reference book. - New Delhi, India, TRAFFIC India and WWF India

31. Uwe Schippmann, Danna Leaman and A.B. Cunnigham, 2006. Medicinal and Aromatic plants. R.J. Bogers, L.E. Craker and D. Lange (eds.), Springer, Netherlands. 75-95.

32. Vinutha M., K.J. Thara Saraswathi and Jayalakshmi N.R. 2013. Effect of sUV-B on essential oil from aerial and sub-aerial parts of Cymbopogon flexuosus(Nees ex Steud) Wats. International Journal of Advanced Research. Vol 1(7): 263-271

33. Zu, Y.G., X.X. Wel, J.H. Yu, D.W. Li, H.H. Pang and L. Tong. 2011. Responses in the physiology and biochemistry of Korean pine (Pinus karaiensis) under supplementary UV-B radiation. Photosynthetica. Vol 49: 448- 458. 